\title{
Implementation of the Cyber Terrorism Prevention, and Rehabilitation Policy in Polda Metro Jaya Police in Central Jakarta
}

\author{
Dian Damayanti \\ Institut IImu Sosial Dan Manajemen STIAMI DKI Jakarta Indonesia \\ DianDamayanti17@gmail.com
}

Received date: 17 August 2020; Accepted date:20 January 2021; Published date: 3 June 2021

Academic Editor: Manique Cooray

Copyright (C) 2021. Dian Damayanti. Distributed under Creative Commons Attribution 4.0

International CC-BY 4.0

\begin{abstract}
Crimes of terrorism are not only done through the internet, but can also be done through networks that can send signals such as telephone communications. By implementing a cyber terrorism policy at the police, terrorism cases will decrease every year. The implementation of this policy helps to overcome the problem of terrorism in Indonesia. This study uses a qualitative method. Based on the results of research and discussion of the implementation of cyber terrorism prevention, and rehabilitation policy at the Polda Metropolitan Police, the implementation following conclusions can be drawn: Researchers in analyzing the of cyber terrorism at the Polda Metro Jaya Police in Central Jakarta used the concept of Van Horn and Van Meter (1975). While the line of communication is already underway, with the existence of cyber patrols to reduce the number of criminal acts involving terrorism in cyberspace, the police are cooperating with parties related to all providers, anti-terrorism agencies and the Ministry of Communication and Informatics. The aim of the implementation of cyber terrorism policies at the central Jakarta police station is to realize domestic security that includes maintaining public security and order, orderly upholding the law, carrying out protection, services to the community, and maintaining public peace by upholding human rights.
\end{abstract}

keywords: policy implementation, Cyber terrorism, Prevention, Rehabilitation and Cybercrime.

\section{Introduction}

The risk of terrorist attacks in Indonesia in recent years can be classified as low. Compared to other countries, there are only a few incentives so far. During the last
5 years there were 121 terrorist cases, where 89 people were killed and 111 injured. Among them there were 7 suicides. In 9 inciedents, a total of 1,310 people have been kidnapped or held hostages, although ransoms are rarely made during the 2013-

Cite this Article as: Dian Damayanti (2021), "Implementation of the Cyber Terrorism Prevention, and Rehabilitation Policy in Polda Metro Jaya Police in Central Jakarta", Journal of Information Assurance \& Cyber security, Vol. 2021 (2021), Article ID 695424, DOI: 10.5171/2021.695424 
2017 period. A terrorist organization in Indonesia, namely Jamaah Ansharut Daulah, has carried out 2 attacks, which killed 27 people and injured 48. Lekagak Tegangati organization had 2 attacks, resulting in 9 killings and 2 injuries. While Jihadi-inspired extremists, 1 attack, with no victims killed and 2 were injured (https://badanpendapatan.riau.go.id/hom e/hukum/8495315769-doc-20170202wa0015.pdf accessed on 13 August 2020 at $14.00 \mathrm{WIB})$.

The legal basis for implementing the cyber terrorism prevention, rehabilitation and reintegration policy is law Number 19 in 2016 article 1, regarding electronic transactions of Electronic Information and / or Electronic Documents and / or printed results that are legal evidence, and law Number 5 of 2018 concerning changes to law number 15 of 2003 concerning the stipulation of government regulations in lieu of law number 1 of 2002 concerning the eradication of criminal acts of terrorism into law.

\section{Literature Review and Previous research}

\section{Implementation Policy}

The policy implementation approach model formulated by Van Meter and Van Horn is called the A Model of the Policy Implementation (1975). This implementation process is an abstraction or the performance of a policy embodiment which is basically deliberately done to achieve a high policy implementation performance that takes place in the relationship of various variables. This model presupposes that policy implementation runs linearly from political decisions, as well as the implementation and performance of public policies. This model explains that policy performance is influenced by several interrelated variables, these variables are:

1. Policy standards and objectives- /measures and policy objectives

2. Resources

3. Characteristics of the implementing organization
4. The attitude of the implementers

5. Communication between related organizations and implementation activities

6. Social, economic and political environment

Van Horn and Van Meter (1975) affect the rate of the successful implementation of the policy. The disposition for Edward III (1980:53) is defined as the tendency, desire or agreement of the executive to implement the policy. If you want to have a policy implemented effectively and efficiently, the executors should not only know what to do and have the willingness to carry out that policy, but they also have to have the will to implement the policy Meter \& Horn (1975:472) state that there are three kinds of response elements that can affect the desire and willingness to implement a policy. These elements include, among others, the knowledge (cognitive), and deep understanding (comprehension and understanding) of the policy; their responses whether accept, reject or neutral (acceptance, neutrality, and rejection); and the intensity of the policy. An understanding of the general intent of the standards and policy objectives is important because after all, a successful policy implementation can fail when the executors (Officials) are not fully aware of the standards and policy goals. Directions disposition of the implementers of the policy goals and standards is also a crucial thing.

\section{Cyber Terrorism}

The world community hopes to predict acts of terrorism before their occurrence because everyone believes that are inevitable. One of the factors that can predict their occurrence is through the methods these groups use to terrify the target population (Brenner, 2002:149). This is where the media relate to terrorism as their means of communication. Terrorism is no longer a local problem for certain countries but an issue that concerns a number of international aspects. Terrorism is an international phenomenon, so the response must also be international (Ganor,2002:130). Terrorists are scattered 
everywhere by using the media as their means of communicating their existence to the whole world. Their communication media start from using books, magazines, newspapers, music, films, software, games ranging from the physical form (hardcopy) to softfiles which are distributed throughout the world (Brenner, 2002:150).

Media and terrorism are two central themes that attract the attention because they have a common thread. The common thread between the media and terrorism cannot be separated from the aspect of news commercialization. Terrorism is a social fact that can be used for the benefit of increasing news consumption. Meanwhile, modern terrorism makes use of communication media to create an effect on audiences through the form of propaganda kind of terror. There is a symbiotic relationship between these two aspects that have a common point of interest, which is the need for information and the desire to be covered by the media. (Sukarno, 2011:360-361). The relationship between terrorists and the media was also revealed by Hendropriyono (2009:218) who stated that there is a mutually beneficial situation (symbiotic mutualism) between terrorists and the media. The media have reinforced terrorist acts as politically out of proportion to what they should be. Terrorism is the deliberate use or threat of using violence against a civil society or against civil society targets, to defend political objectives. The definition of terrorism is based on three important elements according to Ganor (2002: 126) including:

1. The essence of terrorism is in the use of threats or violence. Under this definition an activity that does not constitute violence or the threat of violence will not be defined as terrorism (including non-violent protests, peace demonstrations, tax rebellions, and the like).

2. The objectives of acts of terrorism are always political. Its goals are maintaining political objectives, changing regimes, changing people with power, as well as changing social or economic policies. In the absence of a political goal, a political act cannot be defined as terrorism. An act of violence against civilians that has no purpose is considered $a$, crime or criminal acts not related to terrorism. Some scholars include ideological or religious goals in the list of political goals.

3. The target of terrorism is the civil society. Terrorism exploits the fragility of the civil society to create great anxiety and provoke an intense media reaction by striking against civilian targets.

Al-Qaeda's use of the Internet is based on the reason that mass media such as television and magazines have recently threatened the security of organizations and their members. Television has limited time to broadcast along, dense news as an application of their ideology. Eventhough, mass media are considered unsafe by those who allow their message to be picked up by parties who have an interest and pervert the facts which influence the public opinion on actions they. (Soriano, 2008: 16) Terrorists build a stronger network with the Internet. Even though there are many members who were jailed and died, their act of propaganda are constantly being carried out and expanding, even without a trace in the presence of this Internet.

Referring to the actscarried out by AlQaeda in Pakistan after the American Air Force attacked Damadola Pakistan, they're trying to infiltrate the United States web with its propaganda reminding the Americans that they will continue their terrorism. (Soriano, 2008: 15). Internet provides message boards and chat rooms for recruitment of terrorists, buy bombs, buy airplane tickets, coordinate attacks and gathered in one place without being physically present (Lumbaca \& Gray, 2011: 47). The existence of the Internet they are trying to hack some sites belong to the United States government and some of its Western allies. Therefore, they try to erase their weakness by putting the organization into use new technology.

Osama Bin Laden's organization on it chooses to spread the word development they are mostly currently on the Internet. This internet then gave rise to the term 
cyber-terrorism where a group of terrorists using cyberspace (various Internet applications) in carrying out their acts of terrorism. Internet enables rapid dissemination of information, less risk, and cheap to a variety of constituents, ranging from potential to potential recruitment get prospective partners in the organization terrorists (Seib \& Janbek, 2011: 21).

Many of them using cyberspace, for example a group found Abu Musab AlZarqawi from the Al Qaeda in Saudi has almost never been in direct contact with the mass media, they focus their activities their communication in cyberspace. This method keep them from receiving attention media at large. Paradoxically, the mass media himself using the web to find traces and messages about the latest terrorism they commit which will encourage the emergence of public opinion international. (Soriano, 2008: 15) For Al-Qaeda, the Internet is not the only method to reach for safer and more media fast, but also a turning point of its rise effective communication strategy compared to traditional media. First time to cyberspace able to allow direct communication between terrorists and the public.

The internet is not just fill the limitations of the mass media, but the Internet also allows them to avoid a number of moral rules contained in the media the masses and limit their actions, and this thing profitable for the strategy of acts of terrorism they. As did a group of jihadists along with the 2003 invasion of Iraq, the Internet not only lets them avoid operational risk, but allow them gain access by infiltrating the media system traditional such as Al-Jazeera (Soriano, 2008: 16-17).

\section{Crime Prevention, Rehabilitation}

Crime prevention has come to mean many different things to many different people. Programs and policies designed to prevent crime can include the police making an arrest as part of an operation to deal with gang problems, a court sanction to a secure correctional facility, or, in the extreme, a death penalty sentence. These measures are more correctly referred to as crime control or repression. More often, though, crime prevention refers to efforts to prevent crime or criminal offending in the first instance-before the act has been committed. Both forms of crime prevention share a common goal of trying to prevent the occurrence of a future criminal act, but what further distinguishes crime prevention from crime control is that prevention takes place outside of the confines of the formal justice system. In this respect, prevention is considered the fourth pillar of crime reduction, alongside the institutions of police, courts, and corrections (Waller 2006). This distinction draws attention to crime prevention as an alternative approach to these more traditional responses to crime.

In one of the first scholarly attempts to differentiate crime prevention from crime control, Peter Lejins (1967, p. 2) espoused the following"If societal action is motivated by an offense that has already taken place, we are dealing with control; if the offense is only anticipated, we are dealing with prevention." What Lejins was trying to indicate was the notion of "pure" prevention, a view that had long existed in the scholarship and practice of American criminology (Welsh and Pfeffer 2011). It is this notion of crime prevention that is the chief concern of this volume.

(p. 4) There are many possible ways of classifying crime prevention programs.2 An influential scheme distinguishes four major strategies (Tonry and Farrington 1995b). Developmental prevention refers to interventions designed to prevent the development of criminal potential in individuals, especially those targeting risk and protective factors discovered in studies of human development (Tremblay and Craig 1995; Farrington and Welsh 2007). Community prevention refers to interventions designed to change the social conditions and institutions (e.g., families, peers, social norms, clubs, organizations) that influence offending in residential communities (Hope 1995). Situational prevention refers to interventions designed to prevent the occurrence of crimes by reducing opportunities and increasing the risk and difficulty of offending (Clarke 
1995b; Cornish and Clarke 2003). Criminal justice prevention refers to traditional deterrent, incapacitative, and rehabilitative strategies operated by law enforcement and agencies of the criminal justice system (Blumstein, Cohen, and Nagin 1978; MacKenzie 2006) In Building a Safer Society: Strategic Approaches to Crime Prevention, Michael Tonry and David Farrington (1995a) purposely did not address criminal justice prevention in any substantial fashion This was because this strategy had been adequately addressed in many other scholarly books and, more importantly, there was a growing consensus for the need for governments to strike a greater balance between these emerging and promising alternative forms of crime prevention and some of the more traditional responses to crime. Also important in their decision to focus exclusively on developmental, community, and situational prevention is the shared focus of the three strategies on addressing the underlying causes or motivations that lead to a criminal event or a life of crime. Crucially, each strategy operates outside of the criminal justice system, representing an alternative, perhaps even a socially progressive, way to reduce crime. For these same reasons, we have adopted a similar approach in this volume.

A chief aim of this essay is to provide some background on this view of crime prevention. It also serves as an overview of the key theories that support these three main crime-prevention strategies, important research on effectiveness, and key issues that challenge the prevention of crime. Several observations and conclusions emerge:

- Crime prevention is best viewed as an alternative approach to reducing crime, operating outside of the formal justice system. Developmental, community, and situational strategies define its scope.

- Developmental prevention has emerged as an important strategy to improve children's life chances and prevent them from embarking on a life of crime. The theoretical support for this approach is considerable and there is growing evidence based on the effectiveness of a range of intervention modalities.
- Community crime prevention benefits from a sound theoretical base. It seemingly holds much promise for preventing crime, but less is known about its effectiveness. Advancing knowledge on this front is a top priority. Nevertheless, there are a wide range of effective models in communitybased substance-use prevention and school-based crime prevention.

(p. 5)

- The theoretical origins of situational crime prevention are wide ranging and robust. The strategy boasts a growing evidence base of effective programs and many more that are promising. There is also evidence that crime displacement is a rare occurrence.

- Crime prevention is an important component of an overall strategy to reduce crime and is widely supported by the public over place and time.

A special focus on implementation science and higher quality evaluation designs will further advance crime- prevention knowledge and practice. Striking a greater balance between crime prevention and crime control will go a long way toward building a safer, more sustainable society. Reviewing the findings related to the motives and causes of terrorism, it can be concluded that rehabilitating terrorists is a complex job and requires a concept. This should include an individual assessment, a systematic plan and parameters of effectiveness. With the aim of rebuilding human capacities and functions in society, rehabilitation is always associated with efforts to return to a previous good condition. Rehabilitation must include the following steps: The preparation stage, including the determination of rehabilitation objectives, survey and data collection, analysis and verification of information, initial assessment and needs analysis, detailed rehabilitation arrangements, analysis and risk management, coordination with related parties, preparation prisoners or rehabilitation participants, and prepare trainers or resource persons; The stages of implementation, including general development activities, for example character development, basic economic skills, self-empowerment and specific 
development activities such as religious teachings, woodworking skills, anger management skills; The follow-up stage, which includes ongoing counseling, friendship (discussion or dialogue), evaluation of the success of rehabilitation, receiving feedback for improvement, and community or service involvement. The target of the follow-up stage is prisoners who support ethical and social norms, display a positive attitude, and demonstrate readiness to rejoin the wider community. This aims to maintain the improvements that have been achieved by prisoners or former terrorism activists (Sukabdi, 2015)

\section{Methodology}

Qualitative research is a means for exploring and understanding the meaning individuals or groups ascribe to a social or human problem. The process of research involves emerging questions and procedures. Data typically collected in the participant's setting. data analysis inductively building from particulars to general themes. and the researcher making interpretations of the meaning of the data. The final written report has a flexible structure. Those who engage in this form of inquiry support a way of looking at research that honors an inductive style, a focus on individual meaning. and the importance of rendering the complexity of a situation (Creswell. 2013).

\section{Informant}

- Head of Section of the Special Criminal Regiment cybercrime Unit of the Polda Metro Jaya Central Jakarta Regional Office.

- Head of the special criminal terrorism unit of the Polda Metro Jaya Regional Police of DKI Jakarta Office.

- Head Densus 88.

\section{Research Results, And Research Discussion}

The implementation of the cyber terrorism prevention and rehabilitation policy at the Metro Jaya Police Station in Central Jakarta.
Based on the results of research regarding the implementation of cyber terrorism prevention and rehabilitation policies at the Regional Office of the Jakarta Metro Jaya Regional Police in accordance with Law Number 19 of 2016 concerning Electronic Transactions 1, concerning Electronic Information and / or Electronic Documents which are valid legal evidence and Law number 5 concerning the eradication of criminal acts of terrorism. and using the concept of Van Horn and Van Metter (1975) that policy implementation is influenced by six variables, namely: standards and policy objectives / measures and policy objectives, resources, characteristics of implementing organizations, attitudes of implementers, communication between related organizations and implementation activities.

The social, economic and political environment in the implementation of cyber terrorism prevention and rehabilitation policies at Polda Metro Jaya, Central Jakarta was successful because the implementation of cyber terrorism prevention and rehabilitation policies for the community and the implementer knew what to do, where policy objectives and targets had to be transmitted to the target group, reducing distortions in implementation., reduce the number of crimes to achieve domestic security which includes maintaining security. and public order, orderly and upholding the law, implementing protection, protection and services to the community, as well as maintaining public order by upholding high human rights.

Obstacles have $\begin{gathered}\text { been } \\ \text { faced }\end{gathered}$ in
implementing the policy of
implementing cyber terrorism
prevention and rehabilitation at the
Polda Metro Jaya Police Station in
Central Jakarta

Resource constraints, namely limited expertise such as IT and cyber forensics experts, cyber terrorism. financial constraint is the limited operational budget funds. Crucial problems other than legal 
instruments are the lack of human resources, budget and facilities and infrastructure to support the disclosure of cyber terrorism cases. Currently the budget is only sufficient for one case per month. Whereas in one month there can be up to 15 cases, weak supervision of the use of the internet has the potential to open up opportunities for cyber terrorism. Procedural constraints on the IT Law and those from the Ministry of Communication and Information Technology (KOMINFO) are directly related to policies on the use of information technology and internet facilities in Indonesia and the law of terrorism. From the information obtained by the author from the police, they still do not really understand technology, even many members of the Indonesian cyber police still use computers. It can be said that the ability of Indonesian clinical polyclinics in cyberspace is still at the standard or beginner level.

The efforts made in implementing the cyber terrorism prevention and rehabilitation policy at the Metro Jaya Police Station in Central Jakarta.

There is training by either the police or public or private universities and colleges in information technology faculties. This step needs to be taken to recruit information technology experts, especially students and students who have expertise in the field of IT (Information technology). The roles of lecturers and students are very strategic because they are the ones who can keep up with IT developments. Practitioners can also play an important role in providing input to the government in securing computer networks and the internet. The urgency of the need for experts must also be balanced with the presence of sophisticated and sophisticated facilities and equipment to support network security and also to facilitate tracking criminals so that cases of cyber terrorism can be resolved quickly. in Jakarta it is implemented by empowering and employing cyber experts and experts in Indonesia for network security, although it requires a short time at least these steps can be implemented by the government to reduce the limitations of experts. and the formation of agencies and cooperation between the government and the private sector in countering cyber terrorism. With cyber patrols to reduce the number of crimes involving children in cyberspace, we will cooperate with related parties such as providers and the Minister of Communication and Information. Cyber patrols are conducted to prevent cyber terrorism involving minors and the operation of the cyber terrorism investigation headquarters, the Metro Crime Police Office.

Based on the results of research regarding the implementation of cyber terrorism prevention and rehabilitation policies at the Regional Office of the Jakarta Metro Jaya Regional Police in accordance with Law Number 19 of 2016 concerning Electronic Transactions 1, concerning Electronic Information and / or Electronic Documents which are valid legal evidence and Law number 5 concerning the eradication of criminal acts of terrorism. and using the concept of Van Horn and Van Metter (1975) that policy implementation is influenced by six variables, namely: standards and policy objectives / measures and policy objectives, resources, characteristics of implementing organizations, attitudes of implementers, communication between related organizations and implementation activities.

The social, economic and political environment in the implementation of cyber terrorism prevention and rehabilitation policies at Polda Metro Jaya, Central Jakarta was successful because the implementation of cyber terrorism prevention policies for the community and the implementer knew what to do, where policy objectives and targets had to be transmitted to the target group, reducing distortions in implementation., reduce the number of crimes to achieve domestic security which includes maintaining security. and public order, orderly and upholding the law, implementing protection, protection and services to the community, as well as maintaining public order by upholding high human rights. 


\section{Conclusion}

That policy implementation is influenced by six variables, namely: standards and policy objectives / measures and policy objectives, resources, characteristics of implementing organizations, attitudes of implementers, communication between related organizations and implementation activities.

The social, economic and political environment in the implementation of cyber terrorism prevention and rehabilitation policies at Polda Metro Jaya, Central Jakarta was successful because the implementation of cyber terrorism prevention policies for the community and the implementer knew what to do, where policy objectives and targets had to be transmitted to the target group, reducing distortions in implementation, reduce the number of crimes to achieve domestic security which includes maintaining security. and public order, orderly and upholding the law, implementing protection, protection and services to the community, as well as maintaining public order by upholding high human rights.

Whereas the line of communication is already underway, with the existence of cyber patrols to reduce the number of criminal acts involving terrorism in cyberspace, the police are cooperating with parties related to all providers, the police and anti-terrorism agencies and the Ministry of Communication and Informatics.

Sociocultural approach and community outreach through seminars, training and competitions. Meanwhile, the efforts made in implementing the cyber terrorism eradication policy at the Polda Metro Jaya Police in Central Jakarta are improvements in all aspects, namely when coordinating the division of duties in implementing cyber terrorism policies, there must be an increase in human resources, facilities and infrastructure. Create a special standard operating procedure (SOP) for cyber terrorism because the police do not yet have a standard operating procedure (SOP) for cyber terrorism and still follow the standard operating procedure (SOP) for cybercrime. The aim of the implementation of cyber terrorism prevention and rehabilitation policies at the central Jakarta police station is to realize domestic security that includes maintaining public security and order, orderly and upholding the law, carrying out protection, protection, and services to the community, and maintaining public peace by upholding human rights.

\section{Suggestion}

1. The improvement of the cyber terrorism service delivery system must have experts who must be provided in the DKI Jakarta Polda Metro Jaya Regional Office and good coordination with the Ministry of Communication and Information.

2. Improvements from the private sector are in the form of providing service providers such as Telkomsel, and others. To improve the service system again and impact Implementation of the cyber terrorism policy at the polda Metro Jaya Police Station in Central Jakarta: Increase parental awareness and attention to child, women supervision. The National Police of the Republic of Indonesia has also launched a child protection program on the internet (save children on the internet). State Code and Cyber Codes (BSSN). Sociocultural approaches and community socialization through seminars, training and competitions.

3. Whereas the efforts made in the implementation of the policies to combat cyber terrorism in the DKI Jakarta Regional Office of Jakarta, namely improvements in all aspects, namely when coordinating the division of tasks in implementing cyber terrorism policies, there must be improvements in human resources, facilities and infrastructure Making operational standard procedures (SOP) specifically for cyber terrorism because the police do not yet have standard operational procedures (SOP) for cyber terrorism and are still joining 
cybercrime standard operating procedures (SOPs).

\section{References}

\section{Books}

- $\quad$ Blumstein, Alfred, Jacqueline Cohen, and Daniel S. Nagin, eds. 1978. Deterrence and Incapacitation. Washington, DC: National Academy Press.

- $\quad$ Creswell, J. W. (2013). Qualitative inquiry and research design: Choosing among five approaches (3rd ed.). Thousand Oaks, CA: Sage.

- Hendropriyono, A.M. (2009). Terorisme: Fundamentalis Kriten, Yahudi, Islam. Jakarta: PT Kompas Media Nusantara.

- Seib, P. \& Janbek, D.M. (2011). Global Terrorism and New Media: The post-Al Qaeda generation. New York: Routledge Taylor \& Francis Group

- Waller, Irvin. 2006. Less Law, More Order: The Truth about Reducing Crime. Westport, CT: Praeger.

\section{Edited Books}

- Lejins, Peter P. 1967. "The Field of Prevention." In Delinquency Prevention: Theory and Practice, edited by William E. Amos and Charles F. Wellford. Englewood Cliffs, NJ: Prentice-Hall.

\section{Journal Articles}

- Lumbaca, S. \& Gray, D.G. (2011). The Media As An Enabler For Acts Of Terrorism. Global Security Studies, 2 (1), 46-54.

- $\quad$ Soriano, Manuel R.T. (2008). Terrorism and the Mass Media after Al Qaeda: A Change of Course?. Athena Intelligence Journal, 3 (2), 1-20.

- Sukabdi, Z. A. (2015). Terrorism in Indonesia: A Review on Rehabilitation and Deradicalization. Journal of Terrorism Research, 6(2), 36-56.

\section{Online Journals and websites}

- Brenner, Susan W. (2002). Cyberterrorism: How real is the Threat?. Media Asia, 29 (3), 149-154. doi: https://doi.org/10.1080/01296612.2002. $\underline{11726680}$

- Ganor, Boaz. (2002). Defining Terrorism: Is One Man's Terrorist Another Man's Freedom Fighter?. Police Practice and Research: An International Journal, 3 (4), 287-304. doi: https://doi.org/10.1080/156142602200 0032060

- https://www.worlddata.info/asia/indone sia/terrorism.phpdata accessed on 13 August 2020 at 14.00 WIB

- https://badanpendapatan.riau.go.id/hom e/hukum/8495315769-doc-20170202wa0015.pdf accessed on 13 August 2020 at $14.00 \mathrm{WIB}$

- https://sipuu.setkab.go.id/PUUdoc/1755 28/UU\%20Nomor\%205\%20Tahun\%202 018.pdf accessed on 13 August 2020 at $14.00 \mathrm{WIB}$

- Van Meter, Donald S and Carl, E Van Horn, 1975, The Policy Implementation Proceess A Conceptual Fromework in Administration and Society, Volume 6 No. 4, Sage, BaverlyHills

- Edwards III, George C. (1980). "Implementing Public Policy". Washington DC: Congressional Quartely Press.

- W. Beneran, "Undang-Undang Cyber Crime," $23 \quad 1 \quad 2015$. [Online].Available:http://www.totaltren.c om/2015/01/undangundang- tentangcyber-crime.html accessed on 13 August 2020 at 14.00 WIB

\section{Conference Paper}

- $\quad$ Clarke, Ronald V. 1995b. "Situational Crime Prevention." In Building a Safer Society: Strategic Approaches to Crime Prevention, edited by Michael Tonry and David P. Farrington. Vol. 19 of Crime and Justice: A Review of Research, edited by Michael Tonry. Chicago: University of Chicago Press.

- Hope, Tim. 1995. "Community Crime Prevention." In Building a Safer Society: Strategic Approaches to Crime Prevention, edited by Michael Tonry and David P. Farrington. Vol. 19 of Crime and Justice: A Review of Research, edited by Michael Tonry. Chicago: University of Chicago Press.

- Tonry, Michael, and David P. Farrington. 1995b. "Strategic Approaches to Crime 
Prevention." In Building a Safer Society: Strategic Approaches to Crime Prevention, edited by Michael Tonry and David P. Farrington. Vol. 19 of Crime and Justice: A Review of Research, edited by Michael Tonry. Chicago: University of Chicago Press.

- Tremblay, Richard E., and Wendy M. Craig. 1995. "Developmental Crime Prevention." In Building a Safer Society: Strategic Approaches to Crime Prevention, edited by Michael Tonry and David P. Farrington. Vol. 19 of Crime and Justice: A Review of
Research, edited by Michael Tonry. Chicago: University of Chicago Press.

- Tonry, Michael, and David P. Farrington, eds. 1995a. Building a Safer Society: Strategic Approaches to Crime Prevention. Vol. 19 of Crime and Justice: A Review of Research, edited by Michael Tonry. Chicago: University of Chicago Press.

- Welsh, Brandon C., and David P. Farrington. 2011. "Evidence-Based Crime Policy." In The Oxford Handbook of Crime and Criminal Justice, edited by Michael Tonry. New York: Oxford University Press. 